Keaton, Jeffrey R.; Mishra, Subhendu K.; Clopper, Paul E. Scour at Bridge Foundations on Rock: Overview of NCHRP Project No. 24-29

Verfügbar unter / Available at:

https://hdl.handle.net/20.500.11970/100292

Vorgeschlagene Zitierweise / Suggested citation:

Keaton, Jeffrey R.; Mishra, Subhendu K.; Clopper, Paul E. (2010): Scour at Bridge Foundations on Rock: Overview of NCHRP Project No. 24-29. In: Burns, Susan E.; Bhatia, Shobha K.; Avila, Catherine M. C.; Hunt, Beatrice E. (Hg.): Proceedings 5th International Conference on Scour and Erosion (ICSE-5), November 7-10, 2010, San Francisco, USA. Reston, Va.: American Society of Civil Engineers. S. 749-756. 


\title{
Scour at Bridge Foundations on Rock: Overview of NCHRP Project No. 24-29
}

\author{
Jeffrey R. Keaton ${ }^{1}$ F.ASCE, Ph.D., P.E., Su K. Mishra ${ }^{2}$ M.ASCE, Ph.D., P.E., \\ and Paul E. Clopper ${ }^{3}$ M.ASCE, P.E.
}

${ }^{1}$ Senior Principal Engineering Geologist, MACTEC Engineering and Consulting, Inc., 5628 East Slauson Avenue, Los Angeles, CA 90040; PH (323) 889-5316; email: irkeaton@mactec.com

${ }^{2}$ Senior Technical Advisor, HDR, 2365 Iron Point Road, Suite 300, Folsom, CA 95630; PH (916) 817-4860; email: su.mishrata.hdrinc.com

${ }^{3}$ Senior Hydraulic Engineer, Ayres Associates, 3665JFK Parkway, Building 200, Suite 200, Fort Collins, CO 80525; PH (970) 223-5556; email: clopperparayresassociates.com

\begin{abstract}
National Cooperative Highway Research Program Project 24-29 focuses on time-rate and design depth of scour at bridge foundations on rock. Rock scour is related to five processes: 1) weathering, 2) dissolution, 3) cavitation, 4) plucking, and 5) abrasion. Guidance is provided for identifying scour processes which deserve evaluation. Quarrying and plucking is a threshold process governed by flow velocity, turbulence intensity and block size. Degradable rock scour is cumulative and expressed in terms of stream power which can be accumulated over time. Probability weighted flood frequency captures the range of flow conditions and is converted to average annual scour. Empirical scour number is defined as documented scour divided by cumulative stream power. Geotechnical scour number is calculated from modified slake durability test results. Design scour depth is probability weighted average annual scour times the remaining bridge life or cumulative stream power over a bridge life times the appropriate scour number.
\end{abstract}

\section{INTRODUCTION}

The goals of National Cooperative Highway Research Program (NCHRP) Project No. 24-29 are time-rate of scour and design scour depth at bridge foundations on rock. The guidance from this project will be integrated with Federal Highway Administration Hydraulic Engineering Circular HEC-18, Evaluating Scour at Bridges (Richardson and Davis, 2001). Bridge sites in Florida, Oregon, New York, Utah, and California visited in 2008 provided a range of data and samples for the research. Rock scour modes are considered separately for quantitative scour estimates.

\section{ROCK SCOUR MODES}

Rock scour in natural channels is related to five processes: 1) physical and chemical weathering of exposed rock surfaces, 2) soluble rock dissolution, 3) cavitation, 4), durable rock quarrying and plucking, and 5) degradable rock abrasion. The time between flood events can prepare rock-bed channels for scour in subsequent 
floods. Check-list guidance for determining which scour processes can be dismissed and which deserve evaluation is shown in Figure 1.

\section{Dissolution}

Rocks such as halite, sylvite, and anhydrite can dissolve in water in periods of time short enough to be relevant in engineering application. Such rocks typically hare poor load-bearing capacity and are identified during routine foundation investigations. Common soluble rocks suitable for bridge foundations, such as limestone and dolostone, do not dissolve in engineering time scales. Prehistoric dissolution features of relevance in the context of rock scour consist of solution cavities completely or partially filled with heterogeneous rock rubble in a soil matrix.

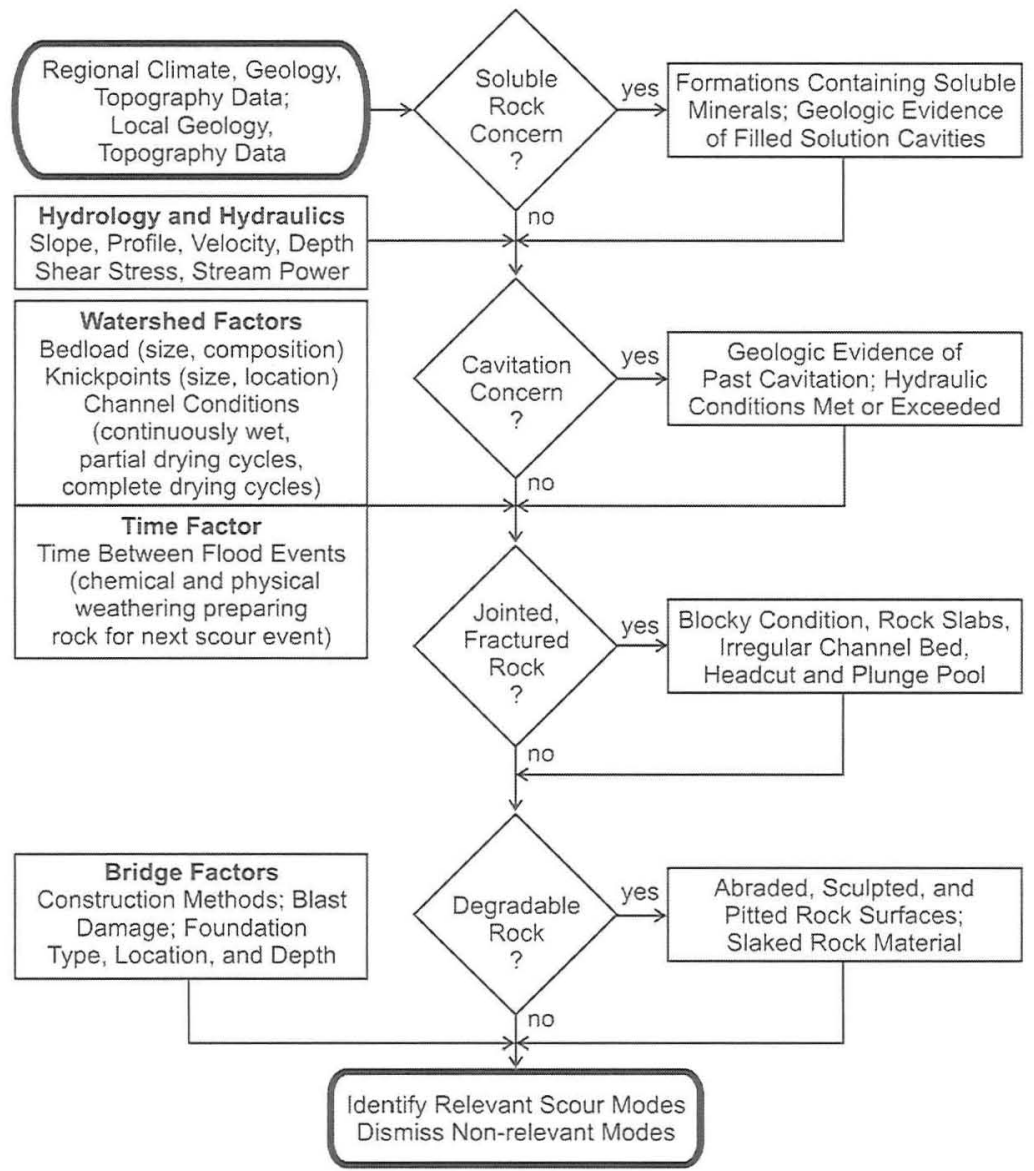

Figure 1. Rock-scour mode flow diagram. 


\section{Cavitation}

Cavitation is an unstable condition in which water vapor forms bubbles that implode, releasing substantial energy. Cavitation can be relatively common in pipes and tunnels but not in natural channels. Water in natural channels rarely reaches the depth and velocity required for cavitation. Turbulence with entrained air mitigates the energy of imploding bubbles because the air is compressible. Mean flow depth and velocity conditions shown in Figure 2 defining likely and possible cavitation were derived from Barnes (1956), Baker and Costa (1987), and Whipple et al. (2000).

\section{Plucking}

Plucking of jointed rock blocks is a threshold process governed by turbulence intensity, flow velocity, and rock block size and geometry. Studies published in geomorphology literature built on flume experiments by Reinius (1986) and provided useful information for defining threshold flow velocities (e.g., Tinkler and Parish, 1998, Hancock et al., 1998). Numerical modeling of threshold flow velocities at bridge piers for rock block plucking and predicted scour depth relative to pier diameter was performed for this project by Bollaert (5th ICSE). An example of threshold velocities for plucking rock blocks is presented in Figure 3.

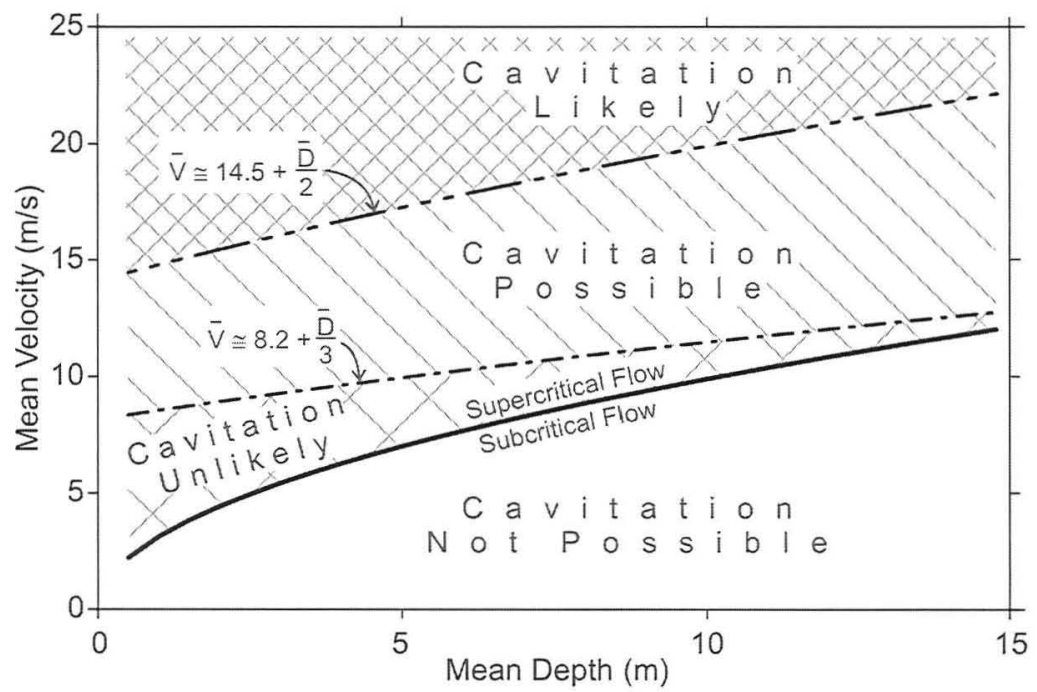

Figure 2. Flow depth and velocity needed for cavitation. Line separating subcritical and supercritical flow corresponds to a Froude number of 1.0. Linear equations on graph are approximate representations of the two curves. 


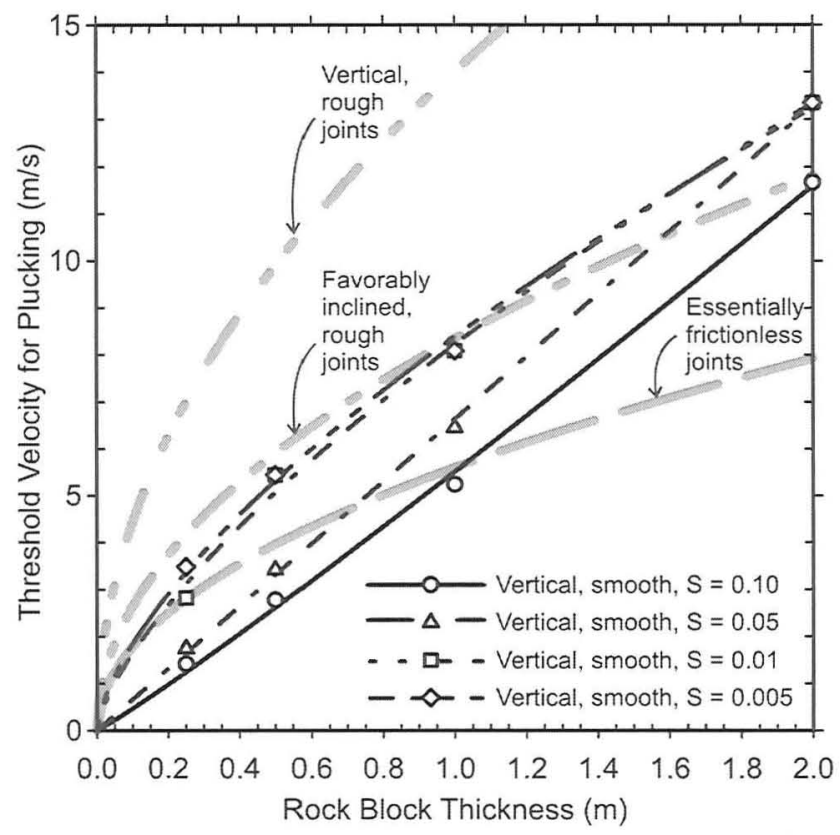

Figure 3. Threshold velocity required for plucking rock blocks. Essentially frictionless joints modified from Hancock et al. (1998); rough joints modified from Tinkler and Parish (1998). Data points and power-function regression curves calculated from data by Bollaert (5th ICSE); $S$ denotes slope.

\section{Abrasion}

Abrasion is gradual and progressive, grain-scale erosion of degradable rock material in response to flowing water with or without saltating bedload. Hydraulic loading for degradable rock material is expressed as stream power (hydraulic shear stress $\times$ flow velocity $=\left[\mathrm{N} / \mathrm{m}^{2}\right] \times[\mathrm{m} / \mathrm{s}]=\mathrm{W} / \mathrm{m}^{2}$ ) because it incorporates all flow parameters and can be accumulated over time (Mishra et al., 5th ICSE). Cumulative stream power is calculated from daily flow series, including consideration of flow duration for various return period discharge events. Relatively long-term scour can be determined from repeated cross sections. Cumulative stream power is used to calculate an empirical scour number as the measured scour depth divided by the stream power accumulated over the same period. An example of an empirical scour number calculation for a bridge on the Sacramento River in Redding, CA, USA, is presented in Figure 4.

Equivalent scour depth and equivalent stream power are calculated from modified slake durability test (ASTM D4644) results (Keaton and Mishra, 5th ICSE). Equivalent scour depth is calculated from weight loss during a test increment divided by the rock material unit weight to produce a loss volume, which is normalized by unit area to give a linear dimension. Equivalent steam power is calculated by 
multiplying the average sample weight during the test increment times equivalent distance traveled during the test increment, dividing the product by cycle duration in seconds, and normalizing the result by the area of the bottom $1 / 8\left(45^{\circ}\right)$ of the test drum where sample fragments reside during slake durability testing. The geotechnical scour number is equivalent scour depth divided by equivalent stream power. An example calculation is presented in Figure 5 for thinly bedded siltstone at the bridge on the Sacramento River in Redding, CA, USA, shown in Figure 4.

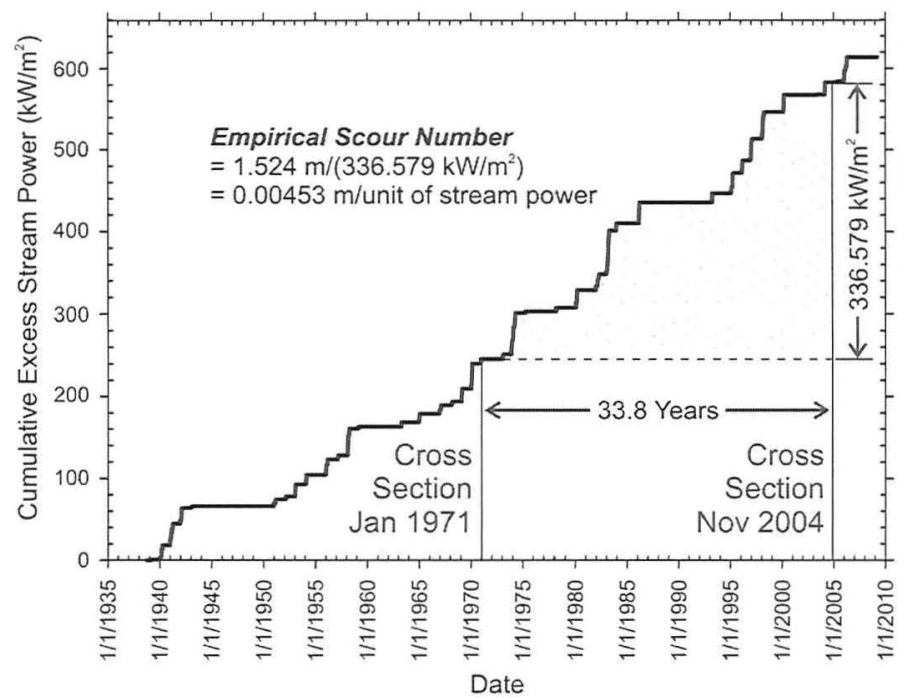

Figure 4. Empirical scour number calculation from daily stream power at the US Geological Survey Keswick gage on the Sacramento River at Redding produced by 2-year and larger discharge events. Cross sections on the upstream edge of a state highway bridge revealed $1.524 \mathrm{~m}(5 \mathrm{ft})$ of scour over 33.8 years.

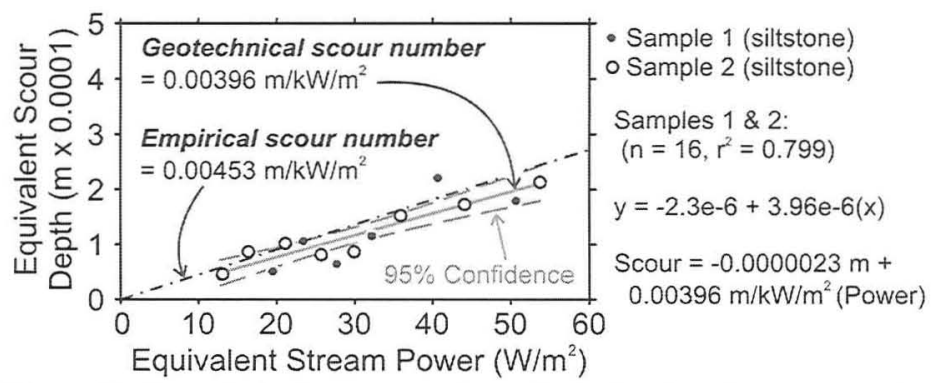

Figure 5. Geotechnical scour number calculation for siltstone samples from the bridge site in Figure 4. Empirical scour number from Figure 4 plotted for comparison. 


\section{SCOUR RATE AND DEPTH}

The time-rate of scour is specific to different scour modes. Dissolution of soluble rocks in water occurs relatively slowly for rocks with suitable load-bearing capacity to support bridge structures. The scour rate of interest for soluble rocks would be governed by void-filling mixtures of rock fragments in a soil matrix too heterogeneous to be generalized. Scour rates in the soil matrix would govern the timerate of scour. Rock blocks and fragments will collect in the scour hole if they are too large to be transported, thereby creating a natural armor condition on the channel bed and limiting the depth of scour.

Scour caused by threshold-controlled processes, such as cavitation or plucking, typically is assumed to develop to the maximum depth rapidly as soon as the threshold condition is exceeded. The depth of cavitation scour in natural channels has not been determined because cavitation is unstable and probably self-limiting by air entrainment and channel adjustments. The depth of plucking has been estimated by index methods (NRCS, 2001; Annandale, 2006) developed largely from empirical data collected in unlined spillway channels. Numerical modeling of threshold flow velocities for rock block plucking performed by Bollaert (5th ICSE) predicted scour depth relative to pier diameter; calibration of the model is needed for hydraulic conditions and geometries of natural channels.

Gradual and progressive scour of degradable rocks can be related to cumulative stream power and the empirical or geotechnical scour number. Flood frequency is calculated from daily flow series if gage data are available; otherwise, it can be estimated using conventional watershed relationships (Mishra et al., 5th ICSE). Flood event discharge is correlated to a cumulative excess stream power and then converted to scour depth by applying the empirical or geotechnical scour number. The inverse of flood return period is frequency; for example, the 2-year discharge corresponds to an average annual frequency of 0.5 , whereas the 100 -year discharge corresponds to an average annual frequency of 0.01 . The area under the probability weighted flood frequency-scour depth curve is the average annual scour, as shown in Figure 6. The examples in Figure 6 consist of the Sacramento River at Redding, Shasta County, CA, and Schoharie Creek at the Interstate Highway 90 crossing in Montgomery County, NY. Shasta Dam on the Sacramento River was closed in 1945 and the discharge has been regulated since that time. Schoharie Creek is an unregulated watershed draining the north side of the Catskill Mountains.

Design scour depth is the product of the probability weighted average annual scour and the remaining life of a bridge structure or the product of cumulative stream power for the life of a bridge and the appropriate scour number. The amount of pier scour at the State Route 273 Bridge on the Sacramento River documented by

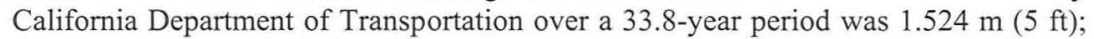
the amount of scour calculated from the average annual scour at this location is $1.6 \mathrm{~m}$ (33.8 $\mathrm{yr} \times 0.048 \mathrm{~m} / \mathrm{yr}$ from Figure 6). The amount of pier scour at the Interstate 90 Bridge on Schoharie Creek determined from forensic studies of the 1987 bridge failure (Resource Consultants and Colorado State University, 1987) was about $4.6 \mathrm{~m}$ $(15 \mathrm{ft})$; the amount of scour calculated from the average annual scour at this bridge is $5.1 \mathrm{~m}(33 \mathrm{yr} \times 0.155 \mathrm{~m} / \mathrm{yr}$ from Figure 6). 


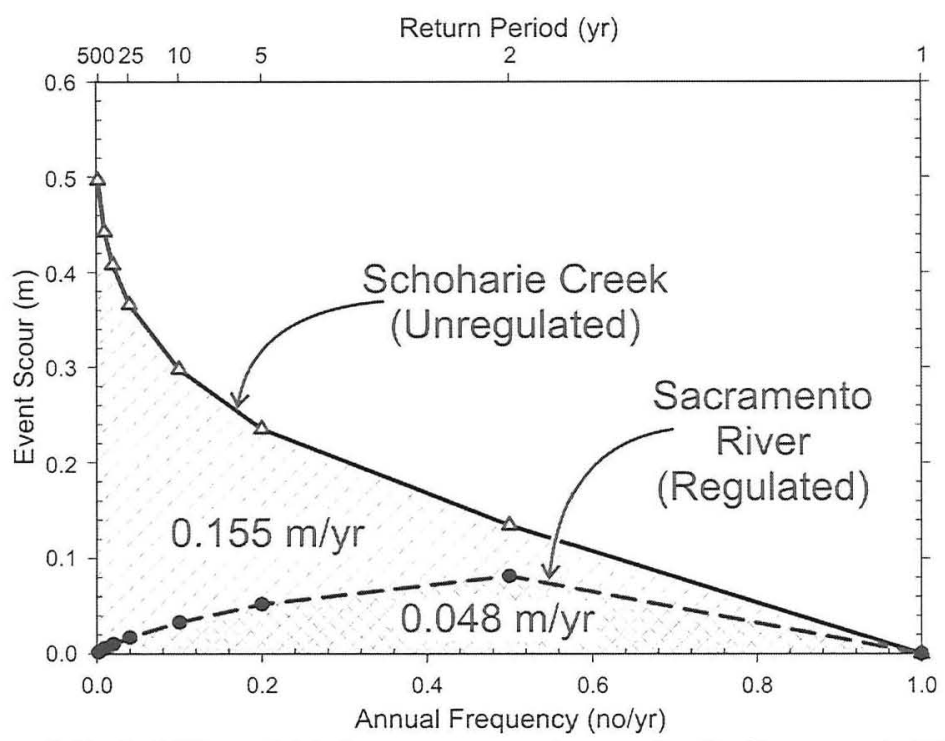

Figure 6. Probability weighted average annual scour for the Sacramento River, CA, and Schoharie Creek, NY. Sacramento River is regulated by Shasta Dam.

\section{DISCUSSION AND CONCLUSIONS}

Rock scour is a rock-water interaction phenomenon. Rock material ranges in properties from slightly better than good soil to much better than the best concrete. No rock material is resistant to the forces of water in the form of waterjets used to strip concrete away from reinforcing steel for bridge deck rehabilitation (Summers, 1995). In fact, waterjets can cut through the reinforcing steel if they are applied long enough. In natural, open channels, however, the stream power tends to be low enough that most rock materials can resist the hydraulic forces to some degree.

Soluble rock dissolution is not likely to be an important process at bridge sites because rocks that dissolve in engineering time have poor load-bearing capacity and would not be used for bridge support. Cavitation is not likely to be an important process at bridge sites because most natural channels cannot support the required hydraulic conditions or such channels would be spanned by bridges.

Durable rock plucking is analogous to scour of giant, interlocking sand grains. Threshold conditions characterized by hydraulic parameters at peak discharge control rock-block plucking similar to sand grains on sand-bed channels. Scour holes in sandbed channels are thought to form rapidly as threshold conditions are reached; the holes are backfilled during waning stages of discharge with sand similar in character to the initial bed. Scour holes in rock-bed channels may be backfilled, but such backfill would not have the resistance of the initial rock-bed channel.

Degradable rock scour is gradual and cumulative. Threshold conditions probably exist, but scour holes develop in response to the applied hydraulic forces. The 100-year discharge may cause scour at a higher rate than the 2-year discharge, 
but if the 100-year discharge duration is very small compared to the 2-year discharge duration, then the overall contribution to scour by the 100 -year discharge would be much less than the 2-year discharge. The probability weighted average annual scour captures this concept. Index methods (NRCS, 2001; Annandale, 2006) applied to Sacramento River conditions show that the hydraulic loading is less than the scour resistance of the siltstone even though $1.5 \mathrm{~m}$ of scour has been documented.

\section{REFERENCES}

Annandale, G.W. (2006). Scour Technology, New York, McGraw-Hill, 430 p.

Baker, V.R., and Costa, J.E. (1987). Flood Power, in Mayer, L., and Nash, D., eds., Catastrophic Flooding, Boston, Allen \& Unwin, p. 1-21.

Barnes, H.L. (1956). Cavitation as a Geological Agent American Journal of Science. v. 254, p. 493-505.

Bollaert, E.F.R. (2010). Numerical Modelling of Scour at Bridge Foundations of Rock, Proceedings $5^{\text {th }}$ International Conference on Scour and Erosion (this conference).

Hancock, G.S., Anderson, R.S., and Whipple, K.X. (1998). Beyond Power: Bedrock Incision Process and Form, in Tinkler, K.J., and Wohl, E.E., eds., Rivers Over Rock: Fluvial Processes in Bedrock Channels, American Geophysical Union, Geophysical Monograph 107, p. 35-60.

Keaton, J.R., and Mishra, S.K. (2010). Modified Slake Durability Test for Erodible Rock Material, Proceedings $5^{\text {th }}$ International Conference on Scour and Erosion (this conference).

Mishra, S.K., Keaton, J.R., Clopper, P.E., and Lagasse, P.F. (2010). Hydraulic Loading for Bridges Founded on Erodible Rock, Proceedings $5^{\text {th }}$ International Conference on Scour and Erosion (this conference).

NRCS (2001). Field Procedures Guide for the Headcut Erodibility Index: Chapter 52, Part 628, National Engineering Handbook, U.S. Department of Agriculture Natural Resources Conservation Service, 210-VI-NEH, revol. 1, March, $37 \mathrm{p}$

Reinius, E. (1986). Rock Erosion, Water Power \& Dam Construction, v. 38, p. 43-48.

Resource Consultants, Inc. and Colorado State University (1987). Hydraulic, Erosion, and Channel Stability Analysis of the Schoharie Creek Bridge Failure, New York, Consulting report prepared for National Transportation Safety Board and New York State Thruway Authority, paginated by section.

Richardson, E.V., and Davis, S.R. (2001). Evaluating Scour at Bridges. Hydrologic Engineering Circular 18, Federal Highway Administration, 4th Edition, Publication No. NHI 01-001, 378 p.

Summers, D.A. (1995), Waterjetting Techology, London, E \& FN Spon, 616 p.

Tinkler, K.J, and Parish, J. (1998). Recent Adjustments to the Long Profile of Cooksville Creek, and Urbanized Bedrock Channel in Mississauga, Ontario, in Tinkler, K.J., and Wohl, E.E., eds., Rivers Over Rock: Fluvial Processes in Bedrock Channels, American Geophysical Union, Geophysical Monograph 107, p. 167187.

Whipple, K.X., Hancock, G.S., and Anderson, R.S. (2000). River incision into bedrock: Mechanics and relative efficacy of plucking, abrasion, and cavitation Geological Society of America Bulletin. v. 112, no. 3, p. 490-503. 